\title{
Status of Development and Manufacture of Solid Oxide Fuel Cell at Topsoe Fuel Cell A/S and Risø/DTU
}

Christiansen, Niels; Hansen, John Bøgild; Holm-Larsen, Helge; Juel Jørgensen, Mette; Wandel, Marie; Hendriksen, Peter Vang; Hagen, Anke; Ramousse, Severine

\author{
Published in: \\ E C S Transactions \\ Link to article, DOI: \\ 10.1149/1.3205518 \\ Publication date: \\ 2009
}

Document Version

Publisher's PDF, also known as Version of record

Link back to DTU Orbit

Citation (APA):

Christiansen, N., Hansen, J. B., Holm-Larsen, H., Juel Jørgensen, M., Wandel, M., Hendriksen, P. V., Hagen, A., \& Ramousse, S. (2009). Status of Development and Manufacture of Solid Oxide Fuel Cell at Topsoe Fuel Cell A/S and Risø/DTU. E C S Transactions, 25(2), 133-142. https://doi.org/10.1149/1.3205518

\section{General rights}

Copyright and moral rights for the publications made accessible in the public portal are retained by the authors and/or other copyright owners and it is a condition of accessing publications that users recognise and abide by the legal requirements associated with these rights.

- Users may download and print one copy of any publication from the public portal for the purpose of private study or research.

- You may not further distribute the material or use it for any profit-making activity or commercial gain

- You may freely distribute the URL identifying the publication in the public portal 


\title{
Status of Development and Manufacture of Solid Oxide Fuel Cells at Topsoe Fuel Cell A/S and Risø DTU
}

\author{
N. Christiansen a , J. B. Hansen ${ }^{\text {a }}$, H. Holm-Larsen ${ }^{\text {a }}$, M. J. Jørgensen ${ }^{\text {a }}$

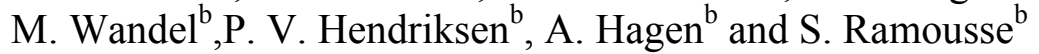 \\ ${ }^{\mathrm{a}}$ Topsoe Fuel Cell A/S, DK-2800 Lyngby, Denmark \\ ${ }^{\mathrm{b}}$ Risø National Laboratory for Sustainable Energy \\ Technical University of Denmark, DK-4000 Roskilde, Denmark
}

Topsoe Fuel Cell (TOFC) provides the SOFC technology platform: Cells, stacks, and integrated stack module for different applications and collaborates with integrator partners to develop, test and demonstrate SOFC applications. The technology development is based on a R\&D consortium with Risø National Laboratory (Risø/DTU) which includes material synthesis and cost effective ceramic manufacturing methods for anode and metal supported flat planar cells in addition to multilayer assembling for compact stacks with metallic interconnects. The development is focussing on high electrochemical performance and durability as well as maximal robustness. In $2008 \mathrm{TOFC}$ has constructed a $5 \mathrm{MW} /$ year cell and stack production facility in Denmark featuring all the necessary unit operations from ceramic powder, continuous tape casting, screen printing, spray painting and sintering to complete stack modules. TOFC's engagement in SOFC technology includes system development in collaboration with system partners and development and manufacturing of integrated stack assemblies called PowerCore.

\section{Introduction}

The very compact TOFC multilayer stack concept with a power density of more than $2 \mathrm{~kW}$ per litre stack volume (1) has been up-scaled to $18 \times 18 \mathrm{~cm}^{2}$ footprint and further optimized for easy manifolding and lower pressure drop with co- or counter-flow configuration. Standard TOFC stacks with a footprint of $18 \times 18 \mathrm{~cm}^{2}$ operate in the $3.2 \mathrm{~kW}$ power range. Larger stack footprints of $18 \times 30 \mathrm{~cm}^{2}$ are currently being constructed for test in 2009. Significant development activity is currently directed towards understanding and solving problems with cell and stack degradation and very promising results have been obtained making it possible to operate cells at higher current densities at very low voltage degradation.

Test of stacks for more than 3000 hours with different selected stack components have revealed that not only the materials and stack components in question but also the fabrication processes have a significant impact on the performance and degradation rate. Segments of the stack currently tested show zero voltage degradation after more than 3000 hours at $0.2 \mathrm{~A} / \mathrm{cm}^{2}$ with simulated pre-reformed natural gas (NG) fuel at $65 \%$ fuel utilisation. 
The first of a new lightweight high power density stack based on a radical modified planar stack design has also been developed and tested in collaboration with United Technologies Research Center. The TOFC delivery is a thermal insulated $2.3 \mathrm{~kW}$ stack including integrated stack compression system optimized with respect to weight and volume for critical mobile applications (1).

Aiming at improved robustness and low material cost TOFC/Risø has increased the efforts towards development of next generation cells with metallic support including novel nano-structured electrodes and Sc-doped zirconia electrolyte materials for operation in the temperature range $600-750^{\circ} \mathrm{C}$. A novel stack design is currently developed where the concept of introducing more metallic parts and metallic seals in the stack design for increased robustness is pursued.

System designs using natural gas, LPG, methanol, DME, ethanol, diesel and ammonia have been studied and optimised. The studies and designs spans from the $1 \mathrm{~kW}$ micro CHP, through $5-10 \mathrm{~kW}$ APU units and $250-500 \mathrm{~kW}$ distributed generation plants to very large coal based hybrid plants.

TOFC is engaged in demonstration activities together with technology partners within the field of several of these promising segments. Test of PowerCore units integrating a stack with a nominal power of $3 \mathrm{~kW}$ with hot fuel processing units such as: Reformer, heat exchangers, catalytic burner, thermal management and instrumentation operating on diesel fuel is planned for 2009. A prototype PowerCore designed for micro CHP application in the $1.4 \mathrm{~kW}$ range has been tested successfully as a part of the national Danish micro CHP program. A scaleable modular multi-stack concept is under development for large SOFC systems. A $10 \mathrm{~kW}$ prototype module is going to be tested in 2009. TOFC has collaborated with Wärtsilä since 2002 on development of SOFC systems for the $200+\mathrm{kW}$ market. Following the successful $20 \mathrm{~kW}$ alpha prototype containing 24 TOFC stacks at Wärtsilä, test of 20 and $50 \mathrm{~kW}$ systems with Wärtsilä are planed for 2009 and 2010 with natural gas, methanol and landfill gas.

\section{Cell Manufacture}

The production facility at Risø jointly operated by Risø and TOFC has served the purpose of production development and supply of standard anode supported cells (referred to as second generation cells) for stack development, test and demonstration activities. The number of $2 \mathrm{G}$ cells produced as well as the production success rate has increased rapidly as shown in Figure 1 . The $2 \mathrm{G}$ cell is based on the classical materials: LSM-YSZ cathode, YSZ electrolyte and Ni-YSZ anode and anode support. Since the so called standard $2 \mathrm{G}$ cell was introduced on a pre-pilot production level in 2004 focus has been on improvement of the manufacturing process aiming at improved performance as well as reduction of rejection rate. The cell size has been scaled up such that cells in the size of $18 \times 18 \mathrm{~cm}^{2}$ are routinely produced. The largest cell manufactured so far is 1250 $\mathrm{cm}^{2}$. The $2 \mathrm{G}$ cell type is very well characterized with respect to performance and durability. The average ASR at $850^{\circ} \mathrm{C}$ is $0.18+/-0.03 \Omega \cdot \mathrm{cm}^{2}$ with a cell degradation rate below $0.6 \% / 1000$ hours for current loads up to $1 \mathrm{~A} / \mathrm{cm}^{2}(2)$. 


\section{$12 \times 12$ cells}

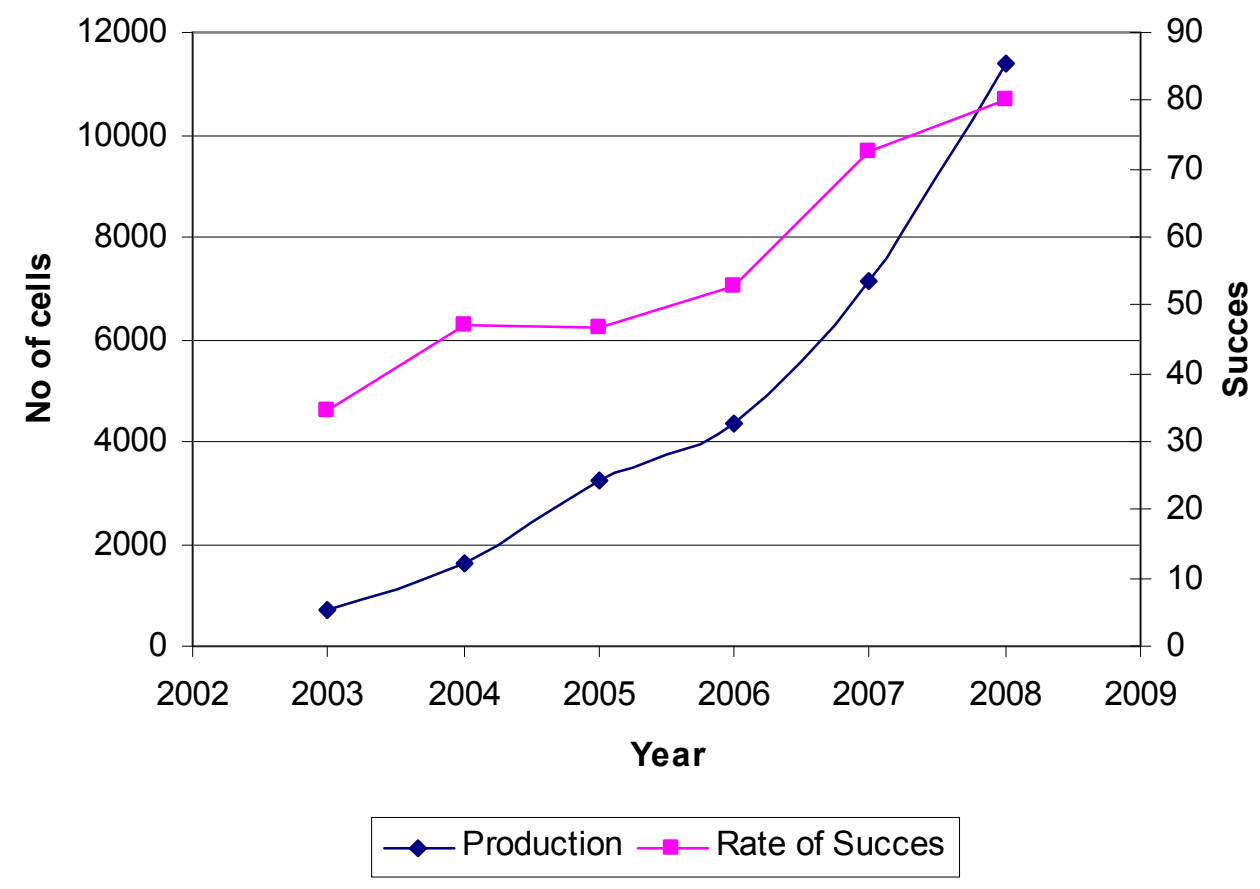

Figure 1. Number of "standard" anode supported $2 \mathrm{G}$ cells produced at the TOFC/Risø operated pre-pilot line a as well as the output yield (right hand axis).

\section{Cell Development}

The development of cells in the TOFC/Risø consortium follows three parallel lines referred to as $2 \mathrm{G}, 2.5 \mathrm{G}$ and $3 \mathrm{G}$, respectively. The $2 \mathrm{G}$ represents the classical anode supported cells with LSM cathodes, whereas $2.5 \mathrm{G}$ represents anode supported cells with LSCF or LSC based cathodes and CGO diffusion barrier layer for operation with high power density at lower temperature. The $3 \mathrm{G}$ is a new metal supported cell with increased robustness and significantly modified and improved electrodes.

\section{More Environmental Friendly Cell Processing.}

Traditional manufacturing of ceramic cells based on tape casting and screen printing involves several potential harmful processing additives such as organic solvents, binders and plasticizers. In order to make the tape casting process more environmentally benign in an industrial manufacturing plant substitution of the traditional slurry additives MEK and plasticizer with environmental friendly additives has been investigated. In traditional ceramic tape casting MEK is used as a solvent. Test of cells based on the new additives including a more environmental friendly plasticizer have shown that the cells perform slightly better than the standard production cells (see Figure 2) Microscopic investigation show that the structure of electrolyte is comparable to that seen for standard cells. 


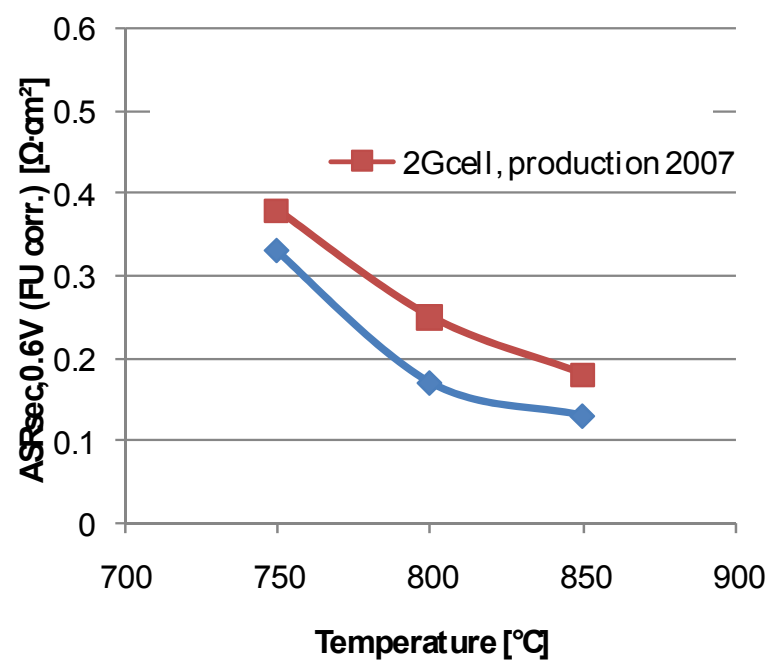

Figure 2. Area specific resistance (ASR) of standard produced cells (upper curve) compared with cells produced without MEK and with new plasticizer (lower curve).

\section{Durability of 2.5G Cells.}

The results of durability tests of $2.5 \mathrm{G}$ cells are shown in Figure 3 . The objective of the test was to measure the degradation rate of the $2.5 \mathrm{G}$ cells at $650^{\circ} \mathrm{C}$ at various current densities with a significant electrode polarisation. The results from aging tests of $2.5 \mathrm{G}$ cells are compared to typical $2 \mathrm{G}$ tests $\left(750{ }^{\circ} \mathrm{C}, 0.75 \mathrm{~A} / \mathrm{cm}^{2}, 75-80 \%\right.$ fuel utilization, $9 \%$ oxygen utilization) in the figure. The current density and degradation rates observed are indicated in the graph.

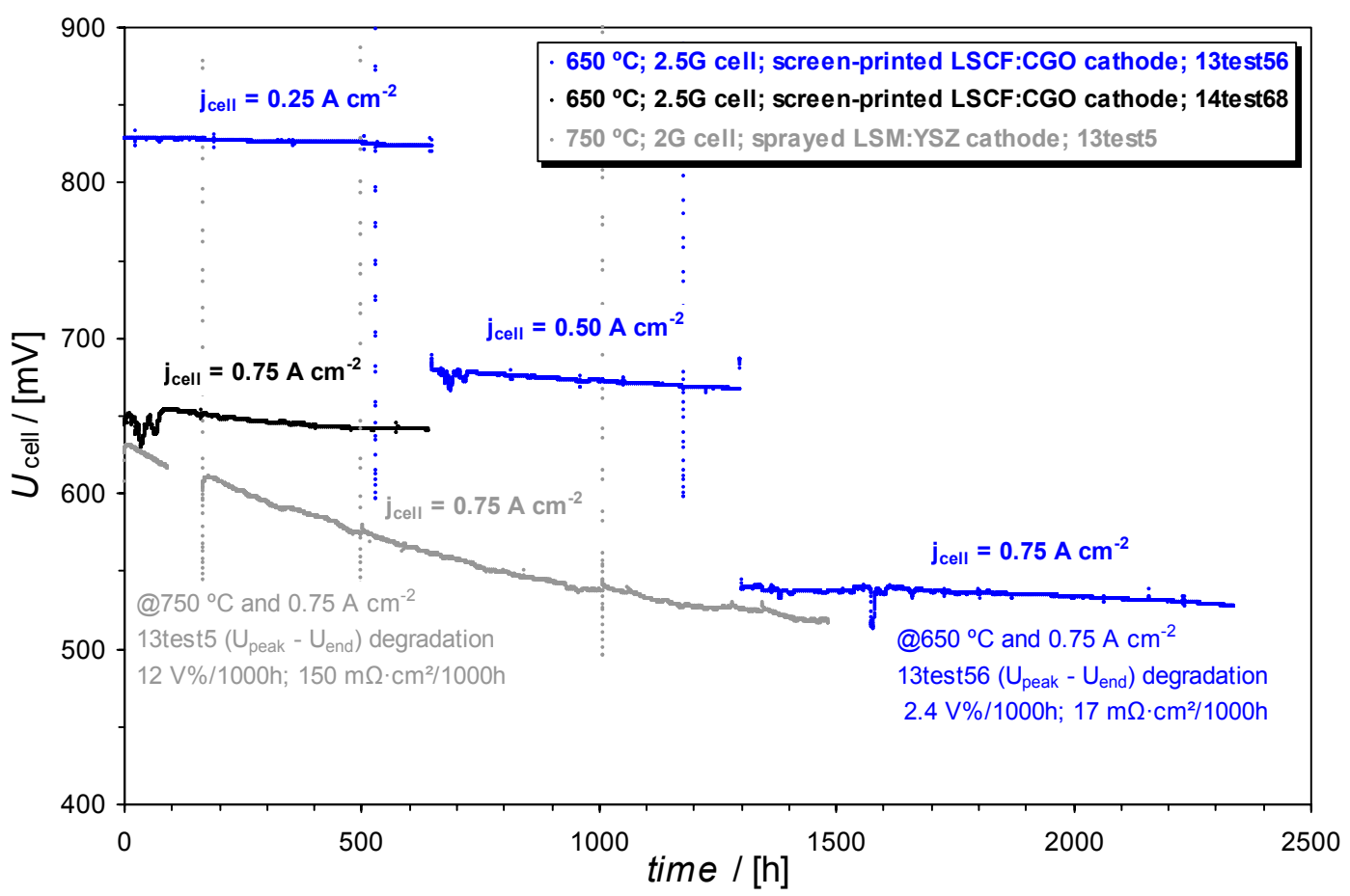

Figure 3. Cell Voltage versus time, with humidified hydrogen as fuel. The grey curve represents the cell voltage with time of a standard $2 \mathrm{G}$ cell at $750^{\circ} \mathrm{C}$ with syn-gas as fuel. 
The test results demonstrate that $2.5 \mathrm{G}$ cells show good stability under galvanostatic operation at $650{ }^{\circ} \mathrm{C}$, even at current densities as high as $0.75 \mathrm{~A} \cdot \mathrm{cm}^{-2}$. Note that the observed degradation rates for the $2.5 \mathrm{G}$ cells are lower than those observed for the $2 \mathrm{G}$ cells at comparable power density.

\section{Development of Metal Supported Cells.}

In addition to enhanced robustness, the metal supported cell concept (3G) offers several other advantages over conventional ceramic cells (electrolyte or anode-supported) such as: Potential reduction in materials cost, reduced thermal stresses, improved red-ox stability, improved thermal distribution during operation and possibilities of improved sealing. However, development of metal supported cells requires a focus on new challenges regarding materials, manufacturing processing and design. Low to medium temperature operation at $600-750^{\circ} \mathrm{C}$ ensures stable material performance. On the other hand decreased operation temperature requires significant improved electrode materials in order to keep high power density during stack operation. The concept of highly active nano-structured electrodes was described in a previous paper (3). The metal supported cells developed in the consortium of TOFC and Risø are based on industrially established component processing analogous the methods used for manufacturing of the anode supported cells.

Currently 3G cells with thin ScYSZ electrolytes are tested on button cells level with an active area of $0.5 \mathrm{~cm}^{2}$. At 655 and $749^{\circ} \mathrm{C}$ the ASR values of the cells are 0.54 and 0.26 $\Omega \cdot \mathrm{cm}^{2}$ respectively with hydrogen $\left(4 \% \mathrm{H}_{2} \mathrm{O}\right)$ fuel. Cell degradation still has to be improved (4). The plan is to test stacks based on metal supported cells with $12 \times 12 \mathrm{~cm}^{2}$ footprint by 2009 .

\section{Cells with Improved Sulphur Tolerance}

For a range of practical fuels and system configurations the cells must show tolerance to some amount of sulphur. A new anode with improved tolerance towards sulphur containing fuels has been developed. It has been proven that these sulphur tolerant cells can withstand 2 ppm $\mathrm{H}_{2} \mathrm{~S}$ over at least 3000 hours, 5 ppm $\mathrm{H}_{2} \mathrm{~S}$ over 500 hours and even $10 \mathrm{ppm} \mathrm{H}_{2} \mathrm{~S}$ over $\sim 100$ hours. (see Figure 4). In addition to the sulphur tolerance considering the electrochemical $\mathrm{CO}$ and $\mathrm{H}_{2}$ oxidation, also the reforming activity seems less poisoned in comparison to standard $2 \mathrm{G}$ cells. The cell has now been running for 5000 hours under different conditions.

\section{Mechanical Strength of Cells}

New metal supported cells (3G) have been tested in 4 point bending at room temperature. Acoustic emission was applied to detect the mechanical failure of the electrolyte. When the metallic support was in tension (and the electrolyte in compression) no failures could be recorded even with very large deformations of the cells. When the electrolyte was in tension metallic yield was observed before failure of the electrolyte. For this bending mode very high Weibull strength of $458 \mathrm{MPa}$ and Weibull module of 20 were observed. Due to a limited number of test specimens the estimated Weibull module is somewhat uncertain. However it can be concluded that the cells are stronger at room temperature than 2G cells based on a ceramic support as illustrated in Figure 5, where the data have 
been rescaled to a smaller specimen volume for comparison to earlier results obtained on $2 \mathrm{G}$ cells (3). Furthermore, Figure 5 shows that the mechanical strength of $2 \mathrm{G}$ cells has been improved by a new improved processing method.
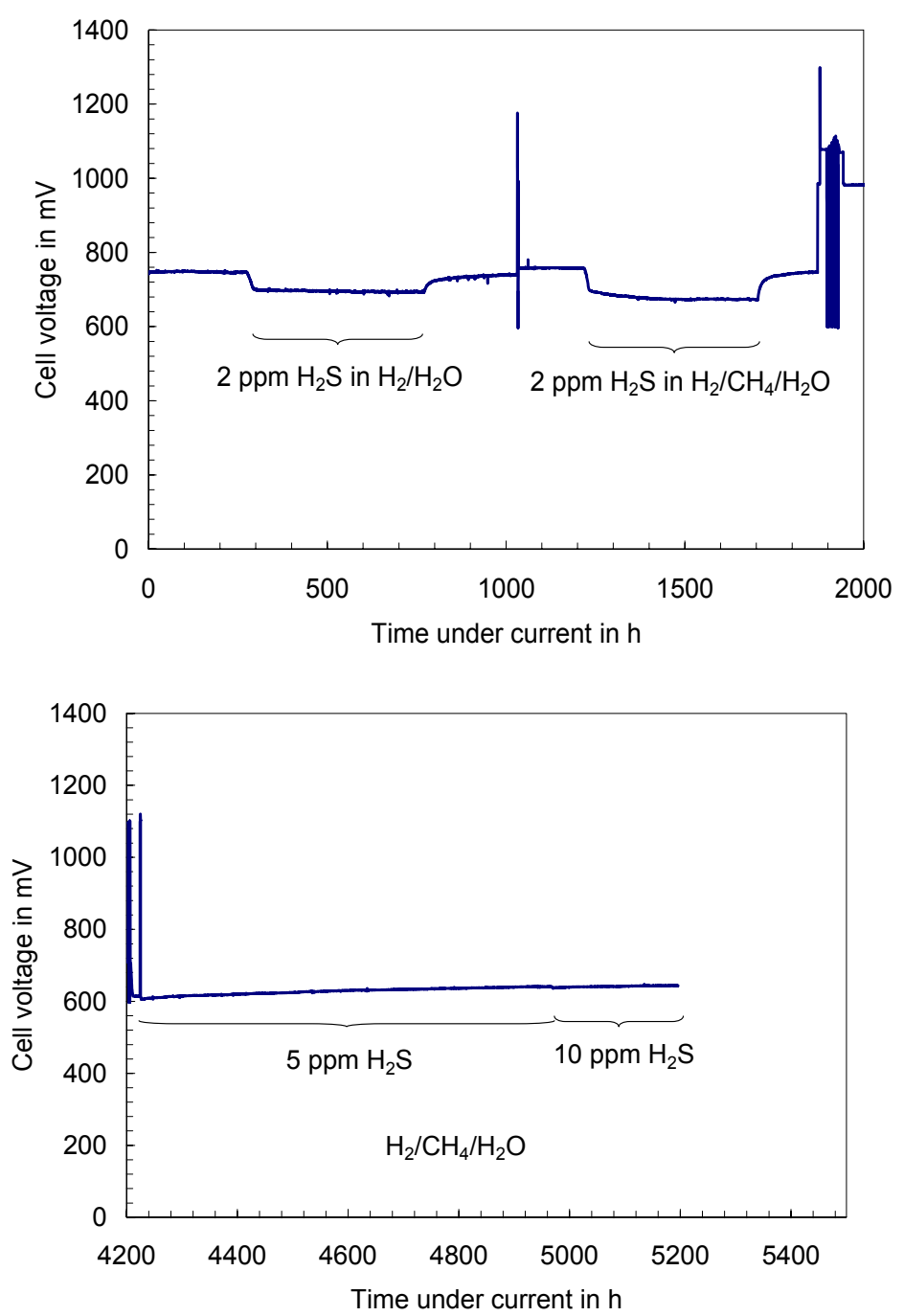

Figure 4. Cell voltage as function of operating time, $850^{\circ} \mathrm{C}, 75 \%$ fuel utilization, $1 \mathrm{~A} / \mathrm{cm}^{2}$ (upper) initially, afterwards $0.44 \mathrm{~A} / \mathrm{cm}^{2}$ (lower).

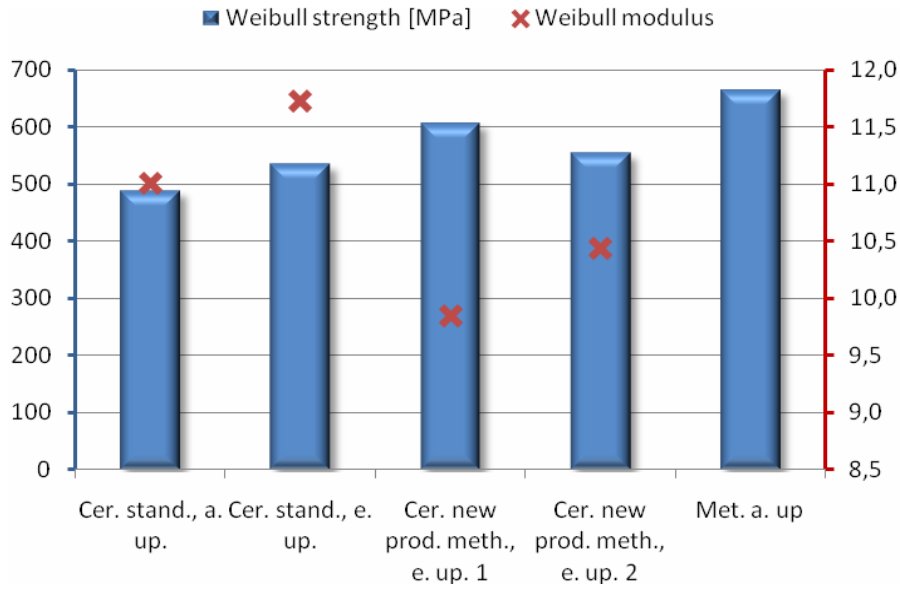

Figure 5. Weibull strengths and Weibull modules of two types of ceramic cells produced with different methods and a metallic supported cell. 


\section{Stack Development}

\section{Stacks with Large Foot Print.}

A specific stack design for $18 \times 30 \mathrm{~cm}^{2}$ cells has been developed. Issues concerned with scaling the stack footprint have been in focus based on TOFC's existing $18 \times 18 \mathrm{~cm}^{2}$ stack design. The optimal flow configuration is described in more details below.

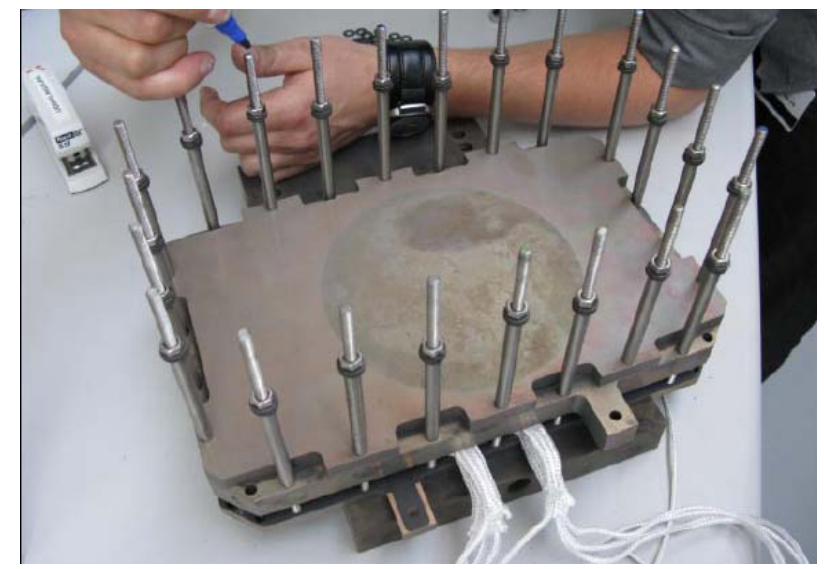

Figure 6. Stack with $18 \times 30 \mathrm{~cm}^{2}$ foot print.

\section{Optimal Flow Configuration}

The TOFC/Risø stack model has been used to elaborate considerations concerning optimal cell dimension and configuration by calculating the distribution of temperature and current density for the four most relevant flow configurations: co-flow or counterflow configurations with the flow directions along the long or the short axes of $18 \times 30$ $\mathrm{cm}^{2}$ cells. The comparisons were made using either constant current or constant $T_{\max }$. Both the short and long flow-configurations work well in the co-flow configuration. In contrast as shown in Table I, the long flow configuration does not work well in the counter-flow configuration. This is due to larger differences in temperatures and current densities along the flow direction. This modelling tool has proved to be very valuable in design of optimal cell dimensions and stack configurations.

Table I. Model comparisons of flow configurations along the short (Case Short) and long (Case Long) axes of the $18 \times 30 \mathrm{~cm}^{2}$ cells for constant current.

\begin{tabular}{|l|l|l|l|l|l|}
\hline \multirow{2}{*}{$\begin{array}{l}\text { Counter-Flow } \\
\text { Configuration }\end{array}$} & Case Short & Case Long & \multicolumn{2}{|l|}{ Case Short } & Case Long \\
\cline { 2 - 5 } & $\mathrm{I}=$ Const & \multicolumn{4}{|l|}{$\mathrm{T}_{\max } \sim$ Const } \\
\hline $\mathrm{P} / \mathrm{W}$ & 4208 & 4695 & 3151 & 887 \\
\hline $\mathrm{I} / \mathrm{A}$ & 84.10 & 93.63 & 61.36 & 16.56 \\
\hline $\mathrm{U} / \mathrm{V}$ & 0.834 & 0.836 & 0.856 & 0.893 \\
\hline$\Delta \mathrm{T} /{ }^{\circ} \mathrm{C}$ & 95 & $154(!)$ & 80 & 86 \\
\hline $\mathrm{T}_{\max } /{ }^{\circ} \mathrm{C}$ & 834 & 867 & 825 & 834 \\
\hline $\mathrm{i} / \mathrm{A} / \mathrm{m}^{2}$ & 2188 & 2188 & 1590 & $388(!)$ \\
\hline
\end{tabular}




\section{Load Cycling of 25 Cell Cross-flow Stack on Simulated Pre-reformed Natural Gas}

Stacks with 25 cells $\left(12 \times 12 \mathrm{~cm}^{2}\right)$ have been subjected to load cycling to analyse potential impact on durability. Cycles were performed with a current ramp rate of 4 to $8 \mathrm{~A} / \mathrm{min}$, corresponding to variation from 20 to $100 \%$ load and vice versa in 2.5 to 5 minutes. No degradation was observed after 350 cycles (se Figure 7).
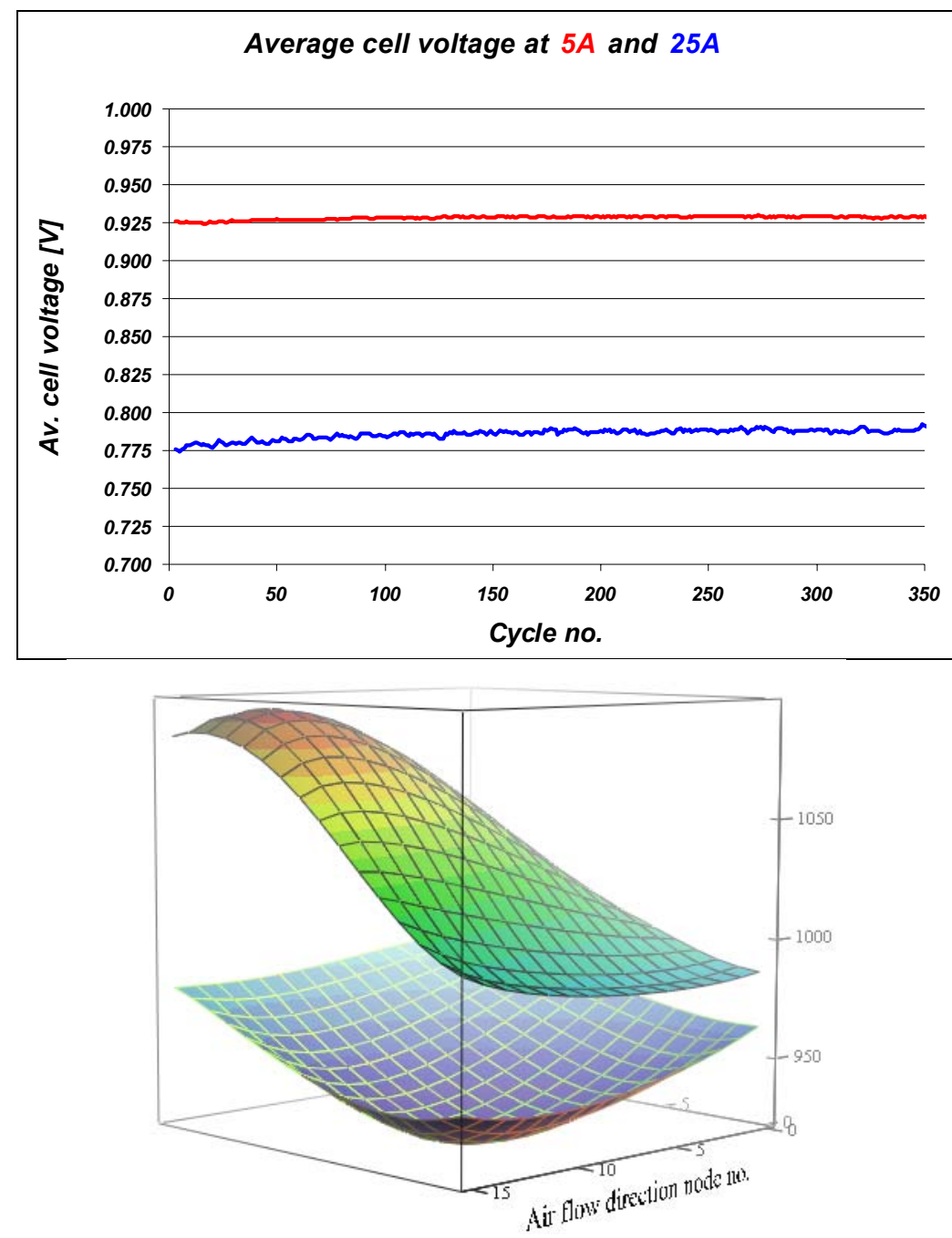

Figure 7. Average cell voltage after 30 minutes of stabilisation at 5A (20\% load) and 25A $(100 \%$ load) measured after each current load cycle (left). Middle cell temperature (Kelvin) profiles for 5 and 25A operating points with identical fuel and air flow (right).

The large differences in profile and fast current ramping induce significant mechanical stress in the cell layers. The induced stresses will be much lower, if air and fuel flow are adjusted along with the current, which is the case in a real system. Hence, this test is significantly more severe than current load cycles experienced by a stack in a real system. None of the 25 cells have failed at the end of the test program.

\section{System Development}

TOFC has during the last year developed a generation one integrated module called PowerCore consisting of the hot components: Stack, heat exchangers, pre-reformer (with 
proprietary Haldor Topsoe A/S catalyst), burner and thermal insulation. A number of these units (shown in Figure 8) have been built and tested with typical max power of 2.2 $\mathrm{kW}$, stable operation power $(1.5 \mathrm{~kW})$ with pre-reformed $\mathrm{NG}$ at $\mathrm{S} / \mathrm{C} 2,65 \%$ fuel utilisation and 50\% DC electrical efficiency. Next generation PowerCore will include anode recycling and further BOP component integration increasing the electrical efficiency to above $60 \%$. The TOFC PowerCores are delivered to system partners for micro CHP system development. Other versions that include CPOX reformer units more suitable for mobile APU application are currently under development.

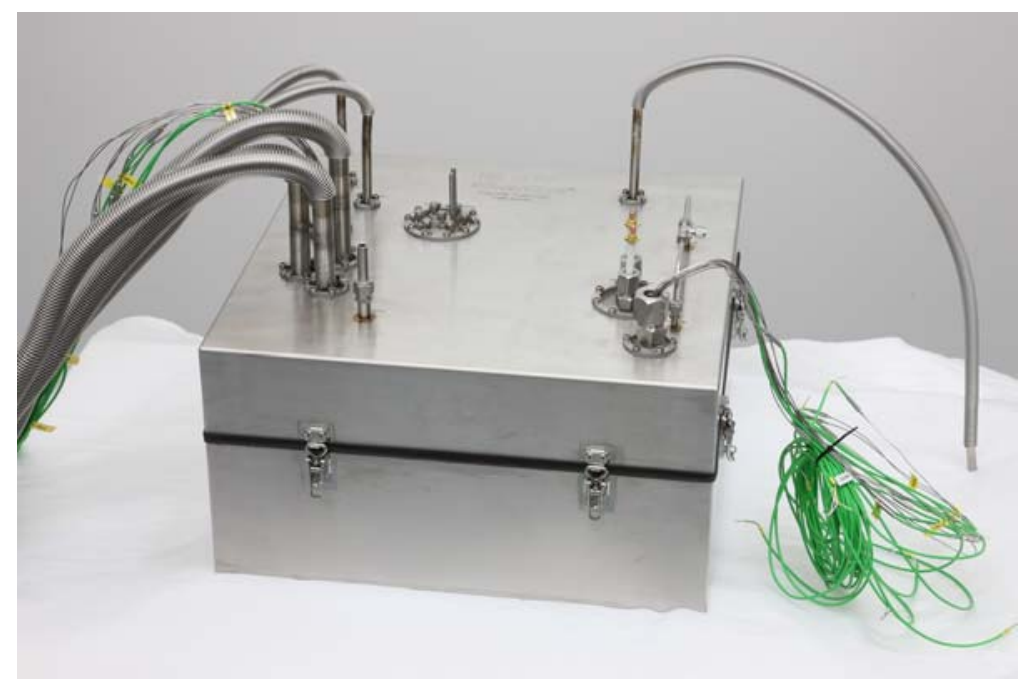

Figure 8. TOFC integrated 1.5 kW PowerCore prototype.

Following the successful $20 \mathrm{~kW}$ alpha prototype at Wärtsilä containing 24 TOFC stacks fuelled with pre-reformed natural gas, 24 TOFC stacks have been delivered to Wärtsilä and installed in a new $20 \mathrm{~kW}$ beta prototype including an adiabatic catalytic reactor containing a proprietary Haldor Topsoe catalyst for methanation of methanol fuel. This unit was started up in May 2009. The base case flow sheet for a methanol based SOFC system is shown in Figure 9.

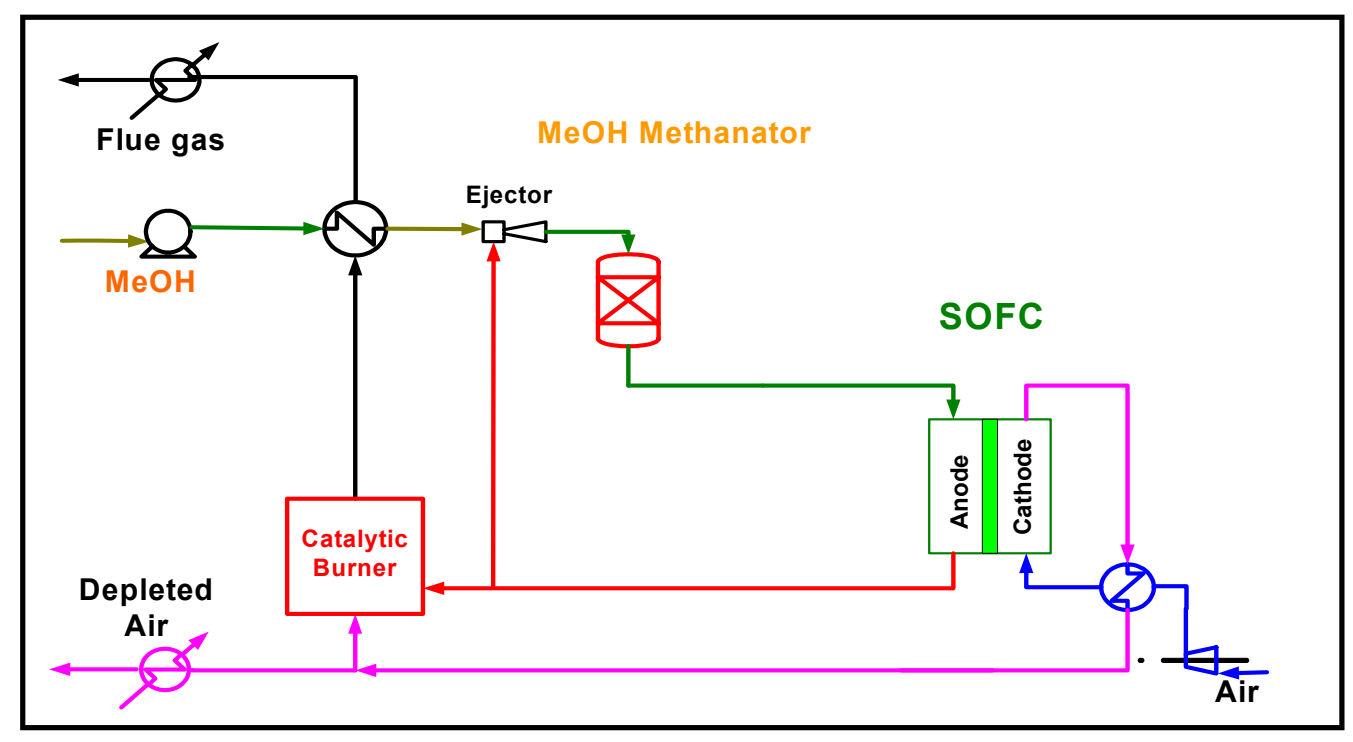

Figure 9. Base case SOFC system with methanation of methanol fuel. 


\section{Acknowledgments}

Energinet.dk, PSO F\&U projects, Danish National Advanced Technology Foundation. EU Life Environment Program. EU Seventh Framework Program METSOFC.

\section{References}

1. N. Erikstrup, M. Drejer, M. Refslund Nielsen, ECS Trans., this volume (2009).

2. N. Christiansen, J. B. Hansen, H. Holm-Larsen. S. Linderoth, P. H. Larsen, P. V. Hendriksen and A. Hagen, ECS Trans., 7, 31 (2007).

3. N. Christiansen, J. B. Hansen, H. Holm-Larsen, M. J. Jørgensen, L. Theil Kuhn, P. V. Hendriksen, A. Hagen and S. Linderoth, European SOFC Forum, Luzerne (2008).

4. P. Blennow, J. Hjelm, T. Klemensø, Å. Persson, K. Brodersen, A. K. Srivastava, H. L. Frandsen, M. Lundberg, S Ramousse, M. Mogensen, ECS Trans., this volume (2009). 